\title{
Genus Pronephrium Presl 1851 (Thelypteridaceae) in Romania
}

\author{
Roxana Pirnea ${ }^{1}$ and Mihai Emilian Popa ${ }^{2 *}$
}

\begin{abstract}
Pronephrium stiriacum (Unger) Knobloch et Kvaček 1976 (Filicales, Thelypteridaceae Holttum 1971) is reported from the Oligocene Petroșani Basin and from the Miocene Bozovici Basin in Romania. Morphological variations of this species, such as size of the leaves, venation and marginal teeth, in the Oligocene-Miocene time interval in Romania are described, discussed and illustrated. The distribution of the Thelypteridacean species Pronephrium stiriacum is also discussed regarding its European expansion during the Cenozoic. Moreover, the palaeoecology of this species is discussed based on taphonomy and occurrences, as Pronephrium stiriacum was a secondary coal generator.
\end{abstract}

Keywords: Thelypteridaceae, Pronephrium stiriacum, Oligocene, Miocene, Romania

\section{Introduction}

The Family Thelypteridaceae is a large filicalean (fern) family segregated by Holttum (1971) from the Family Dryopteridaceae, having many recent representatives such as Thelypteris Schmid, Cyclosorus Link, Cyclogramma Tagawa, Coryphopteris Holttum, and Pronephrium Presl, among other genera. The family occurs especially in subtropical and tropical Asia, where they record a higher biodiversity, with a few European representatives. Today, genus Pronephrium includes about 70 tropical species. Cenozoic representatives of genus Pronephrium, especially Pronephrium stiriacum, are recorded widely in Europe and in the world, especially in the Oligocene and Miocene continental formations (Figs. 1 and 2).

For this work, Pronephrium stiriacum was collected from two Romanian coal basins, the Petroșani Basin and the Bozovici Basin (Fig. 2). This species was also cited or described by previous authors from the Transylvanian Basin (Givulescu 1968; Petrescu 1968, 1970; Petrescu et al. 1987). Both the Petrosani and Bozovici basins are the Cenozoic molasse, intramontaneous, coal-bearing basins with well preserved, compressive and permineralized floras.

\subsection{Geological setting}

The Petroșani Basin is mainly the Oligocene in age, with a strong coal-mining industry which enabled fossil

\footnotetext{
* Correspondence: mihai@mepopa.com

${ }^{2}$ Faculty of Geology and Geophysics, Department of Geology, Laboratory of Palaeontology, University of Bucharest, 1, N. Bălcescu Ave, 010041 Bucharest, Romania

Full list of author information is available at the end of the article
}

collecting in underground, from extraction galleries as well as sterile dumps (Popa 2011). The fossil flora of the Petroșani Basin occurs mainly in the Chattian Dâlja-Uricani Formation (Fig. 3), which yields 19 bituminous coal seams extracted from several coalfields. Other formations of the Petroșani Basin such as the Rupelian Cimpa-Răscoala Formation and the Aquitanian Lonea Formation are less fossiliferous (Fig. 3). Coals were reported from the Petroșani Basin since 1826, and coal extraction quickly became intensive, for steel and for energy (Răileanu et al. 1963; Petrescu et al. 1987; Preda et al. 1994). The palaeoflora of the basin was reported since the nineteenth Century, as Stur (1863) published the first detailed geological report in which fossil plants were cited for the first time. Heer (1872) described 27 plant taxa, followed by Staub (1887) who described 96 taxa and by Pax (1908) who revised the previous palaeobotanical works, discussing 32 taxa. Răileanu (1955) and Mateescu $(1956,1960)$ studied the geology and the coal sequences, citing and describing various plant species. Petrescu and Givulescu (1986) and Petrescu et al. (1987) provided palaeoecological reconstructions, and Givulescu (1996) contributed with a modern revision of the Petroșani Basin palaeoflora. Unfortunately, few samples in the historical collections were found by the authors of this paper from the Petroșani Basin, from other areas/formations in Romania (such as Bucharest, Cluj-Napoca, Brașov or Timișoara; Fig. 2), or from abroad (Vienna). Intensive fossil collecting in the basin was undertaken by the authors since 2014, from underground mining horizons and 


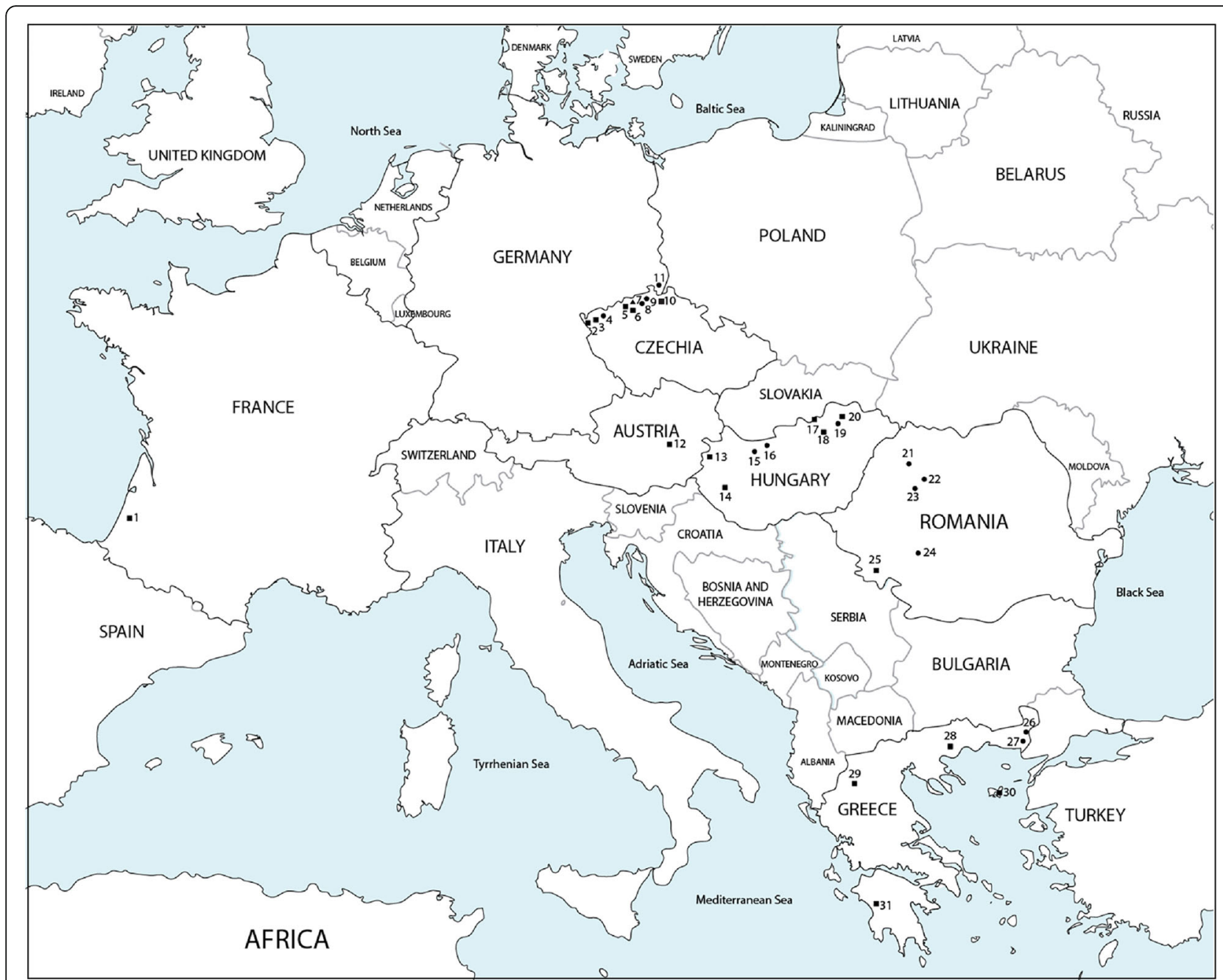

Fig. 1 Occurrences of Pronephrium stiriacum in Europe: 1 - Arjuzaux; 2 - Cheb; 3 - Sokolov; 4 - Doupovske Mts.; 5 - Most; 6 - Dobrčice; 7 - Kučlín; 8 Kundratice; 9 - Suletice; 10 - Chotyně; 11 - Seifhennersdorf; 12 - Parschlug; 13 - Sé; 14 - Balatonszentgyörgy; 15 - Környe; 16 - Csolnok; 17 - Ipolytarnóc; 18 - Visonta; 19 - Eger; 20 - Felsőtárkány; 21 - Jac; 22 - Cornești; 23 - Coruș; 24 - Petroșani; 25 - Bozovici; 26 - Lagina; 27 - Fylakton; 28 - Strymon; 29 Grevene; 30 - Lemnos; 31 - Pyrgos. Symbols: Black triangle - Eocene in age; Black circle - Oligocene in age; Black square - Miocene in age

from sterile dumps or outcrops in the area. Pronephrium stiriacum was previously collected from Aninoasa and Lupeni coalfields, in some cases with a precise stratigraphic position within the Dâlja-Uricani Formation.

The Bozovici Basin is a less studied Romanian coalbearing basin (Răileanu et al. 1963; Petrescu et al. 1987; Preda et al. 1994), and mainly includes the Miocene Lăpușnicul Mare Formation with two members (Codrea 2001): the Burdigalian (Eggenburgian) Pârâul Lighidia Member and the Langhian (Badenian) fossiliferous Valea Slătinicului Member. Up to nine lignite seams occur to the top of the Valea Slătinicului Member, with highly fossiliferous roof shales as well as rich, fossiliferous beds in between the seams (Fig. 4). The Miocene flora of Bozovici is both compressive and permineralized, with peculiar cases of petrifaction of tree trunks (Preda and Nedelcu 1987; Preda et al. 1994). The flora was only briefly cited by Pop (1959) as a part of one of the first geological works in the area, followed by the contribution of Iliescu (1967). Today, the coal mining activities have almost ceased in the Bozovici Basin, but intensive fossil collecting was still undertaken by the authors in former open cast mines and in outcrops of the area.

\section{Materials and methods}

The Romanian material is represented by compressions on hand specimens collected from two basins of the South Carpathians: the Petroșani Basin, Oligocene in age, and the Bozovici Basin, Miocene in age.

The studied Oligocene material was collected from several places within the Petroșani Basin: the underground of Aninoasa coal mine, Lupeni, Vulcan and Uricani sterile dumps. The Aninoasa material has the largest and the best-preserved Oligocene fragment, and 


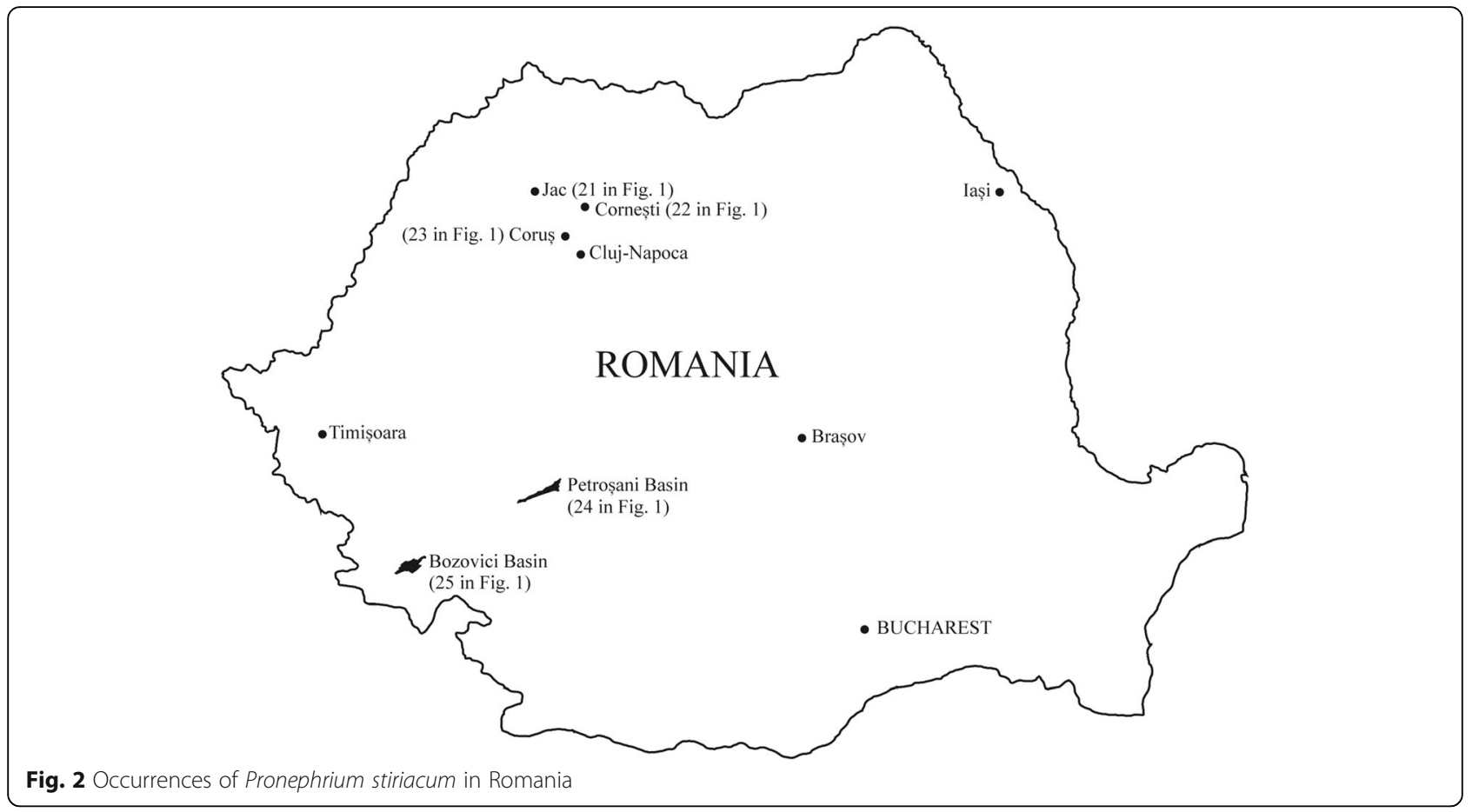

although it is fertile, its sori are missing. This fragment occurs on a sample studied at the Mining Museum in Petroșani, and it has a precisely recorded stratigraphic position: it has been collected from the roof shale of the coal seam no. 17 (Fig. 3). The material curated at the National Geological Museum of the Geological Institute of Romania in Bucharest includes five hand specimens, three belonging to the Emil Pop Collection (P-21224 and P-21225 from Aninoasa, and P-21228 from Vulcan), one belonging to the Stefan Mateescu Collection (P-20775 from Uricani), and an unknown collector (P-26708) also from Uricani. The supplementary material was collected in 2017 by one of the authors (R. Pirnea) from the Lupeni sterile dump. It includes 17 hand specimens curated at the University of Petroșani (UPLU0010, 0055, 0077, 0075, 0078, 0082, 0084, 0088, 0091, 0092, 0096, 0101, 0104, 0108, 0109, 0110, 0112). Among these samples, UPLU0082 hosts the largest fragment from Lupeni, UPLU0108 has the best-preserved fragment from the area, while UPLU0010 has a fragment which is fertile but poorly preserved.

The Miocene material was collected by one of the authors (M. E. Popa) from the Lighidia quarry, Bozovici Basin, in 2015. The Bozovici material is preserved as impressions on red and grey porcelanites, on three samples: LPBUV-0614 (fertile), and LPBUV-0612 and LPBUV-0613 (sterile). The sterile fragments are badly preserved, but the fertile fragments still yield sporangia.

Macrophotographs were undertaken using a Panasonic DMC-L10 digital camera with an Olympus Zuiko
$35 \mathrm{~mm}$ Macro lens together with a Kaiser copy-stand and Ikea lights, using a lateral illumination for detailing morphological features (Popa 2011). In the field, a Canon Powershot G12 camera was used. More detailed photographs were taken using a Carl Zeiss Stemi 2000C dissecting microscope, with a Carl Zeiss PCL 1500 LCD light source, a Canon A640 camera and with Axiovision Extended Focus software for z-stacking.

\section{Systematics}

Phylum Pteridophyta

Class Filicopsida

Order Filicales

Family Thelypteridaceae Holttum 1971

Genus Pronephrium Presl 1851

Pronephrium stiriacum (Unger) Knobloch et Kvaček 1976

Figs. 5, 6, 7, 8

1847 Polypodites stiriacus Unger, pp. 121-122, pl. 36, figs. 1, 2, 3, 4, 5;

1976 Pronephrium stiriacum Knobloch et Kvaček, p. 12, pl. 1, fig. 1;

1985 Pronephrium stiriacus Hably, pp. 11, 23, 24, 26, 27;

1986 Pronephrium stiriacus Givulescu, p. 179;

1986 Pronephrium stiriacum Petrescu et Givulescu, p. 110; 1991 Pronephrium stiriacum Kvaček et Hably, p. 52, pl. 1, fig. 2;

1995 Pronephrium stiriacum Kvaček et Walter, p. 39, text-fig. 4, pl. 1, fig. 1; 


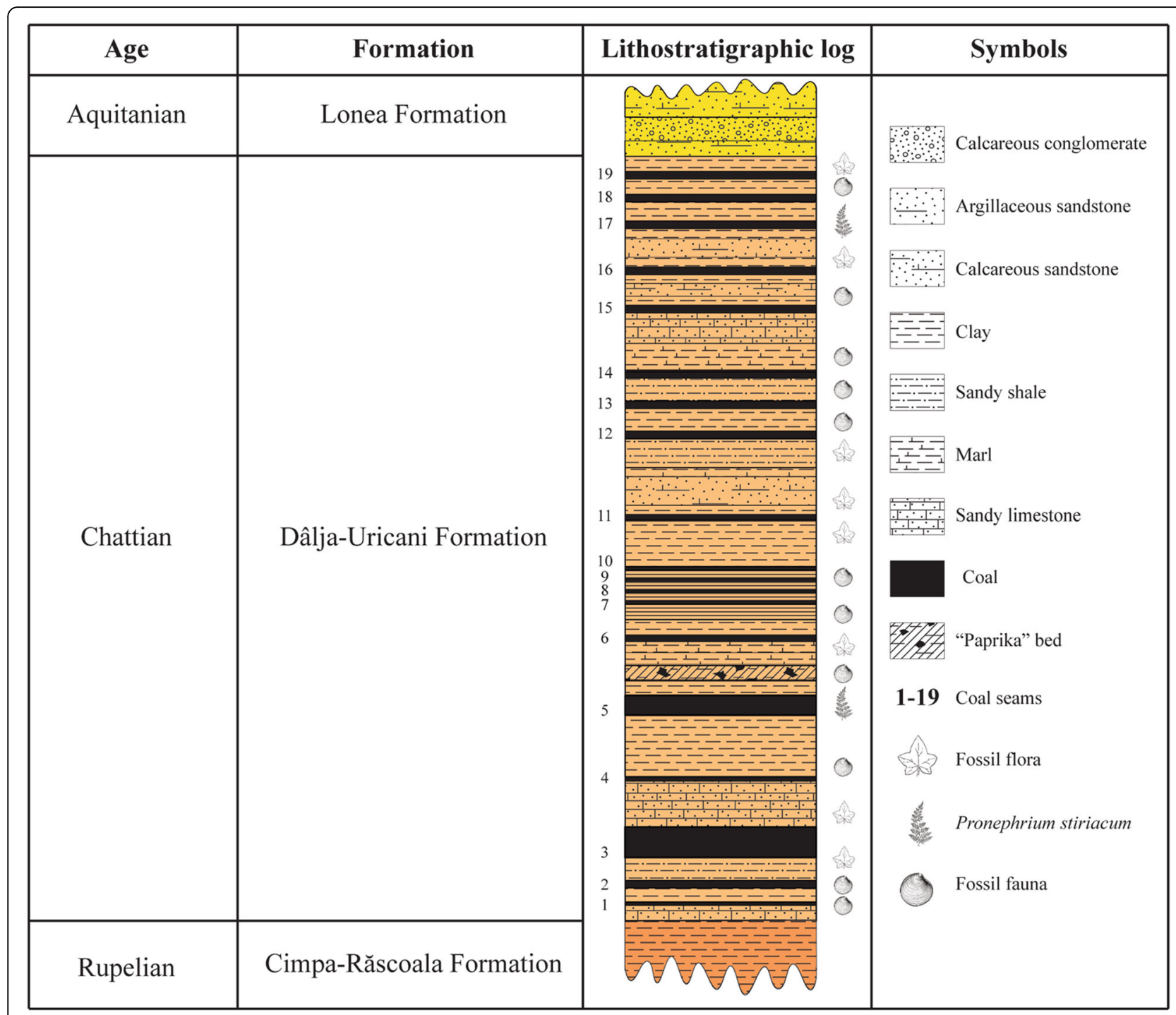

Fig. 3 Synthetic lithostratigraphic log of the Oligocene coal-bearing formations of the Petroșani Basin (Cimpa-Răscoala, Dâlja-Uricani and Lonea formations), South Carpathians, Romania

1996 Pronephrium stiriacus Givulescu, pp. 15-17, pl. 30, fig. 1;

1997 Pronephrium stiriacum Petrescu et al., p. 39, pls. 1, 20, figs. 3, 6;

1998 Pronephrium stiriacum Kvaček et Walter, p. 25, pl. 13, fig. 9;

1999 Pronephrium stiriacum Givulescu, p. 27, pl. 1, fig. 5;

2000 Pronephrium stiriacum Kvaček et Hurnik, p. 4, text-fig. 1.1, pl. 1, figs. 1, 2;

2004 Pronephrium stiriacum Kovar-Eder et al., p. 52, pl. 1, fig. 3;

2004 Pronephrium stiriacum Erdei et Wilde, p. 120, text-fig. 7;

2007 Pronephrium stiriacum Kvaček et Teodoridis, pp. 391, 395, 400, 402, 403;
2007 Pronephrium stiriacum Teodoridis, p. 416;

2007 Pronephrium stiriacum Walter et Kvaček, p. 91, pl. 1, figs. 1, 2, 3, 4, 5, 6, 7, 8;

2011 Pronephrium stiriacum Kvaček et al., p. 10, pls. 1, 9, figs. 1, 15;

2013 Pronephrium stiriacum Hably, pp. 39-40, pls. 1, 35, figs. 2, 3, 4, 5;

2013 Pronephrium stiriacum Hably et Magyar, p. 17; 2014 Pronephrium stiriacum Velitzelos et al., pp. 58, 59, pl. I, figs. 1, 2, 3;

2015 Pronephrium stiriacum Hably et al., p. 287, fig. 3.

\subsection{Description}

\subsubsection{The Petroșani Oligocene material}

The hand specimen from Aninoasa yields three exceptional fragments, a large fragment exposing the abaxial 


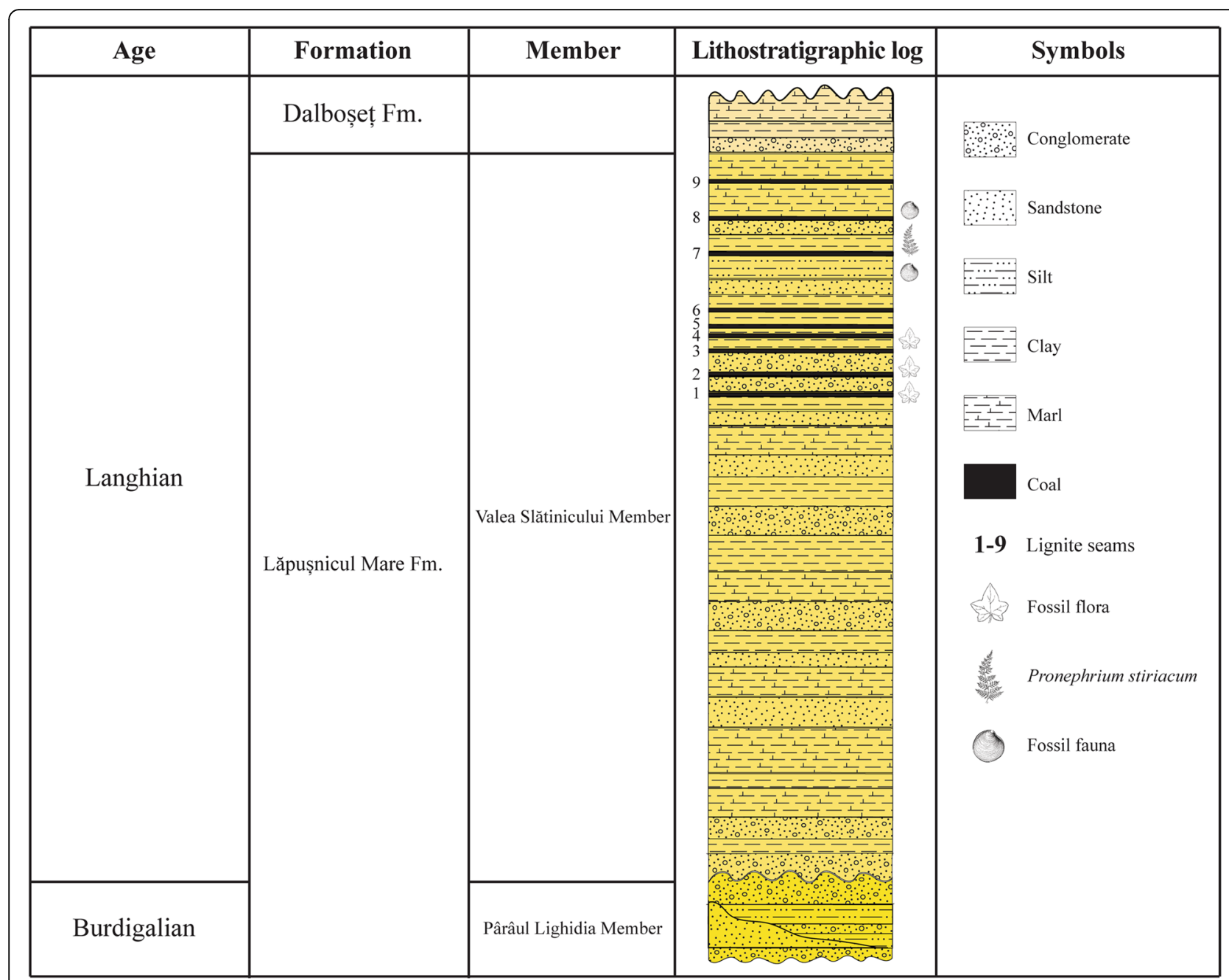

Fig. 4 Synthetic lithostratigraphic log of the Miocene coal-bearing formations of the Bozovici Basin (Lăpușnicul Mare and Dalboșeț formations), South Carpathians, Romania

surface of the leaf (F1), an apical fragment exposing the adaxial surface (F2) and a small, detached pinnule (F3; Fig. 5, with fragments marked with F1-F3). The leaf is unipinnate and imparipinnate, with pinnules having a thin lamina substance. The apical part of the frond has an elongated apical pinnule prolonging the rachis (Figs. 5, 6). The primary rachis is $3-4 \mathrm{~mm}$ wide, $4 \mathrm{~mm}$ wide at the base of the fragment, $3 \mathrm{~mm}$ wide to the apical end of the fragment, while the length of the fragmented rachis is $170 \mathrm{~mm}$. The rachis is straight, smooth, with a longitudinal, short and slightly rounded median ridge (Figs. 5, 6). In cross section, the rachis is triangular or $\mathrm{V}$-shaped. No clear hair bases or scales occur along the primary rachis. The pinnules are strongly elongated in shape, lanceolate, short petiolate, with an asymmetrical base, dentate margins and acute apex (Figs. 5, 6, 9a). The petiole is less than $1 \mathrm{~mm}$ long and $1 \mathrm{~mm}$ wide. The pinnules are inserted suboppositely to alternately to the rachis, with angles between $45^{\circ}-50^{\circ}$ (Fig. 5). The basiscopic part of the pinnule's base is rounded, and the acroscopic part of the base is straight, parallel to the rachis (Figs. 5, 6). The pinnules are 100-170 $\mathrm{mm}$ long and 10-15 $\mathrm{mm}$ wide at the base, where they are the widest. The usual width of the pinnules varies between $14-15 \mathrm{~mm}$. The pinnule margins are dentate, with falcate and wide teeth, sometimes even slightly mucronate, separated by narrow and shallow sinuses. The teeth are usually $0.5-0.7 \mathrm{~mm}$ long, while the smallest pinnules are weakly dentate (Figs. 5, 6, 9a). The venation is prominent abaxially and weakly expressed adaxially. The midrib is $0.9-1 \mathrm{~mm}$ wide, rounded or slightly ridged abaxially, slightly depressed adaxially, straight, reaching the pinnule's apex. No hair bases occur along the midrib (Figs. 6a, c, 9a). The secondary veins are straight, inserted oppositely to suboppositely to the midrib. Each secondary vein reaches the apex of a marginal tooth. The secondary veins are very narrow, about $0.2 \mathrm{~mm}$ wide. The tertiary veins are straight, inserted oppositely to the secondary veins, interconnected to the neighboring 


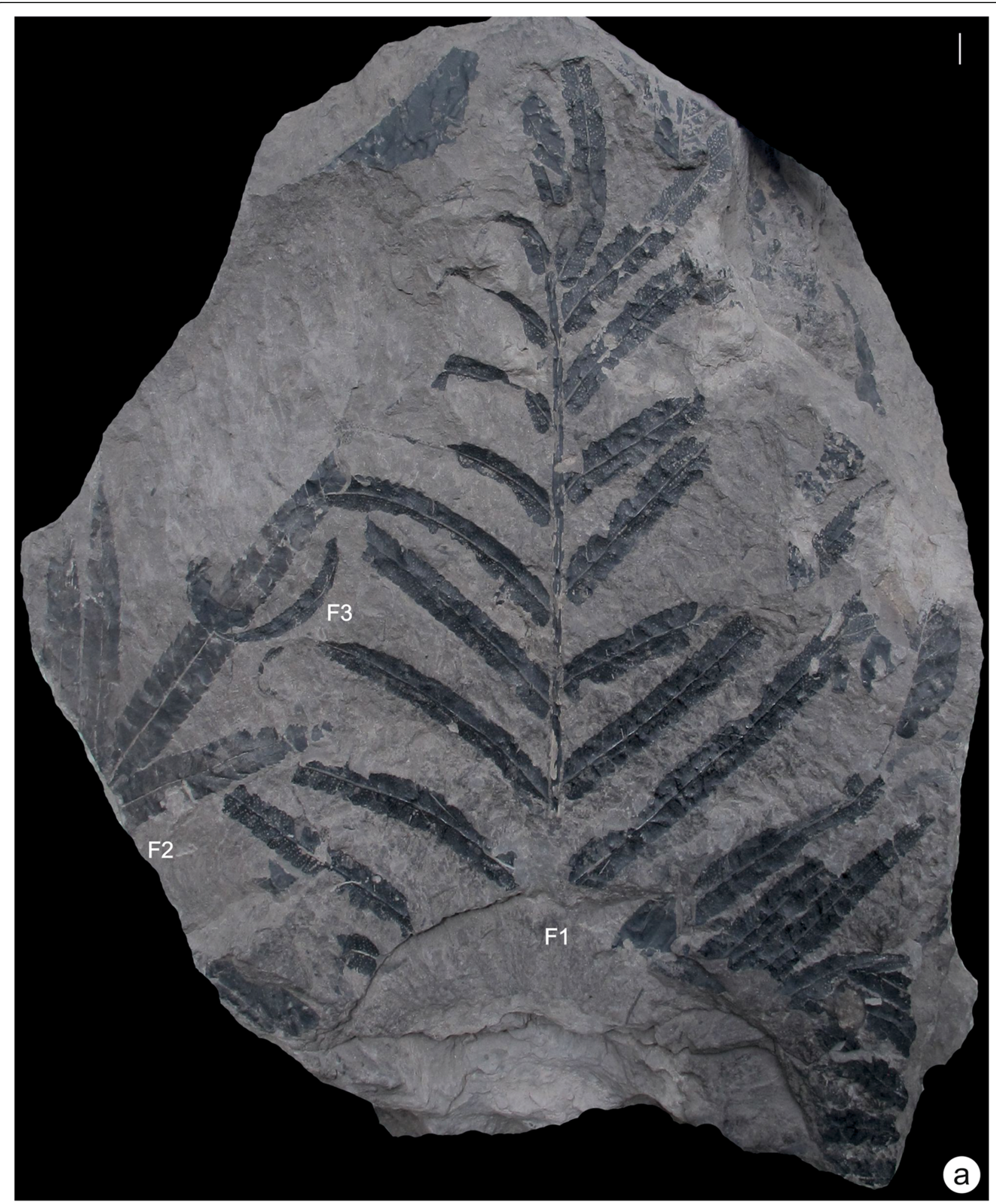

Fig. 5 Pronephrium stiriacum from Aninoasa, roof shale of coal seam no. 17, Oligocene, Petroșani Basin, general view. F1, F2, F3: Pronephrium stiriacum leaf fragments. Hand specimen no. 1, Mining Museum in Petroșani. Scale bar: $10 \mathrm{~mm}$

tertiary veins along a straight, interconnecting vein reaching each sinus between two neighboring marginal teeth (Fig. 6b, c). The sori occur in the middle of each tertiary vein and the interconnecting vein (Figs. 6b, 7a, 9a). Each sorus is circular, about $0.6-0.8 \mathrm{~mm}$ in diameter. Unfortunately, all sori are missing along the tertiary veins, leaving 

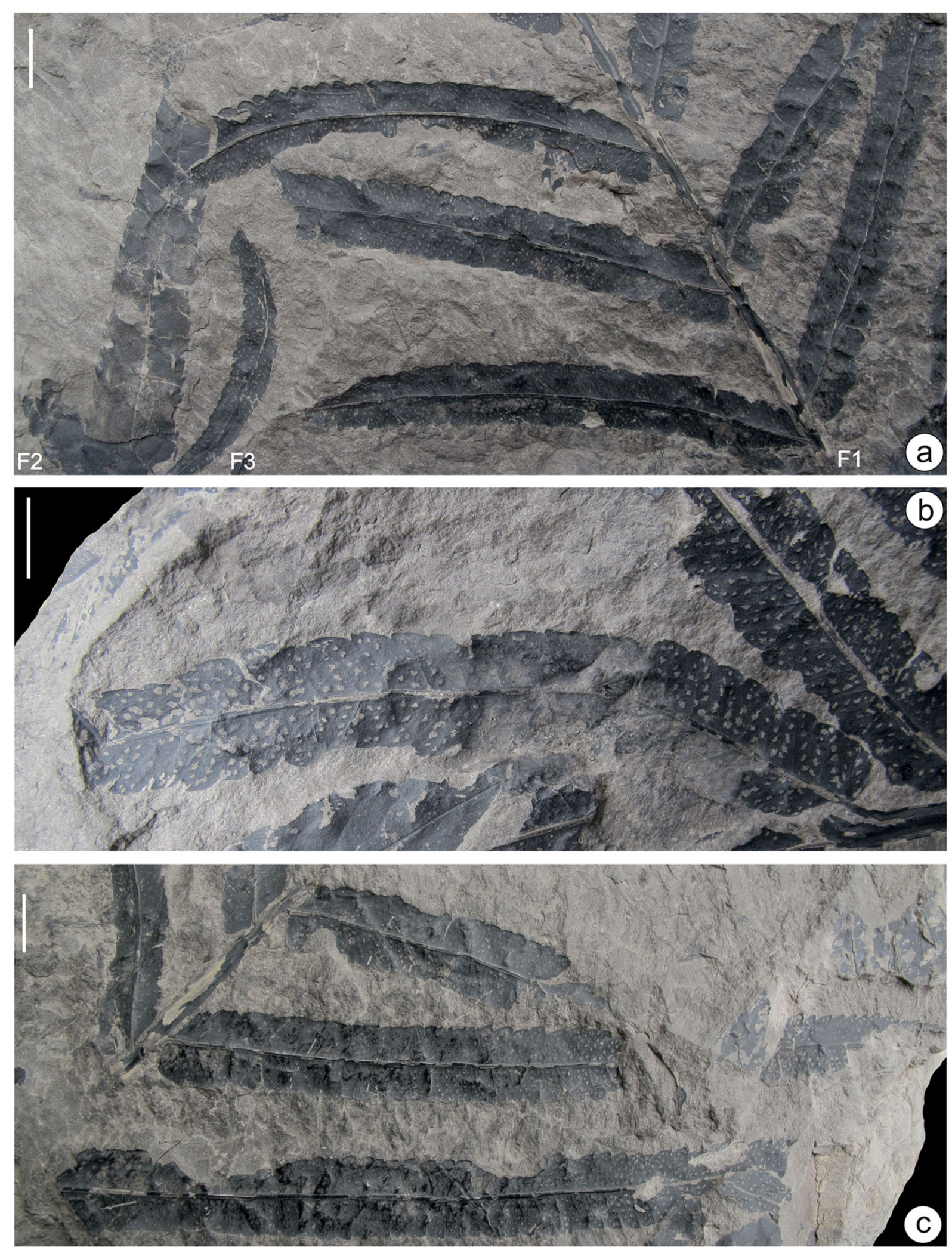

Fig. 6 Pronephrium stiriacum from Aninoasa, roof shale of coal seam no. 17, Oligocene, Petroșani Basin. a Details of leaf fragments F1 (abaxial view), F2 (abaxial view) and F3 (apical fragment, adaxial view); b-c Details of pinnules of leaf fragment F1 in abaxial view, showing the primary rachis, petioles, asymmetric bases, venation, dentate margins and missing sori. Hand specimen no. 1, Mining Museum in Petroșani. Scale bar: $10 \mathrm{~mm}$ 

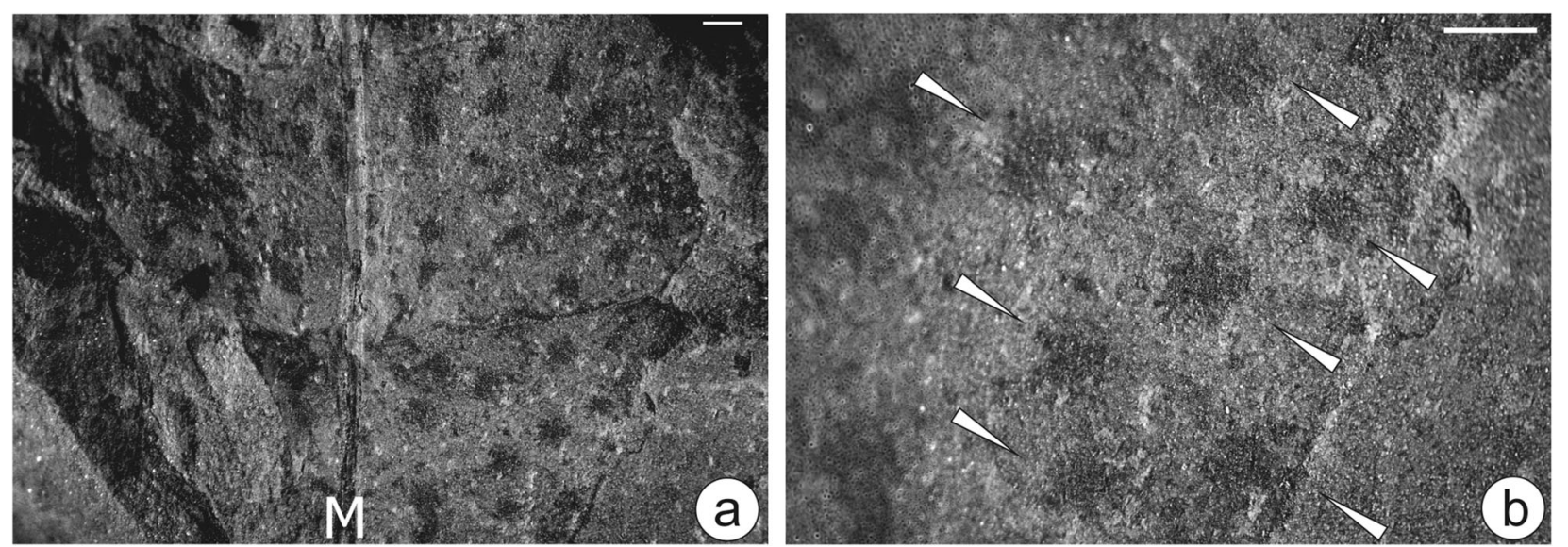

Fig. 7 Pronephrium stiriacum, fertile fragment, from Lupeni sterile dump, Oligocene, Petroșani Basin. a Fragment of a fertile pinnule, showing the midrib $(M)$, secondary veins, tertiary veins, connecting veins and sori; b Detail of the same fertile fragment, with arrows indicating the poorly preserved sori. Hand specimen UPLU0010, University of Petroșani. Scale bars: $1 \mathrm{~mm}$

a circular piercing in the thin lamina. The only exception is a poorly preserved fertile fragment occurring on the hand specimen UPLU0010 from the Lupeni sterile dump, with sori reaching $0.6-0.8 \mathrm{~mm}$ in diameter (Fig. 7). These sori are irregular clusters of sporangia, very difficult to separate due to the poor preservation (Fig. 7). They usually occur to the middle part of the tertiary veins, uniformly distributed between the midrib and pinnule margins.

\subsubsection{The Bozovici Miocene material}

The collected material includes only dispersed pinnules, both sterile and fertile. The pinnules are short petiolate, elongated in shape, linear, with a slightly asymmetric base, with strongly dentated margins and acute apices (Fig. 8a, b). The marginal teeth are symmetrical, with a slightly attenuated apex, and they are separated by a symmetrical, wide sinus. The pinnules' length varies between $40-60 \mathrm{~mm}$, and their width varies between 10$15 \mathrm{~mm}$, with the widest part toward the pinnule base. The petiole is $4-5 \mathrm{~mm}$ long and $0.5 \mathrm{~mm}$ wide, ornamented with fine longitudinal striae (Fig. 8b). The midrib is $0.5-0.7 \mathrm{~mm}$ wide, finely striated longitudinally, with a short ridge along the abaxial surface. The rachis is marked along its abaxial surface by rare dots representing large trichomial bases (Fig. 8b, c). The secondary veins are more prominent abaxially, they are inserted oppositely to the midrib at angles between $70^{\circ}-80^{\circ}$, and they are straight, smooth, reaching each apex of the marginal tooth (Figs. 8c, d, 9b). The tertiary veins are also straight, inserted oppositely to the secondary veins, and about five tertiary veins along each secondary one. Their tertiaries interconnect with their neighboring counterparts, thus a supplementary vein is generated, reaching each marginal sinus (Figs. 8c, d, 9b). In fertile pinnules, the sori occur along the tertiary veins in the middle region between the secondary veins and the supplementary veins (Figs. 8c, d, 9b). They are usually circular, $0.7-1.0 \mathrm{~mm}$ in diameter and few reniform (Fig. 8d, middle one), with numerous small, spherical sporangia distributed irregularly but clustered. Nearly $12-17$ sporangia occur in each sorus, but their precise number is difficult to assess. No indusium and no in-situ spores were observed (Fig. 8c, d). Their distribution is uniform, occurring in the middle, between connecting veins and secondary veins, always on the tertiary veins.

\subsection{Remarks}

We consider pinnules as the large, petiolate, laminate and dentate structures attached to the primary rachis. Indeed, in morphology, these large structures seem very similar to structures generated by fusing into large pinnae of smaller, neighboring pinnules with simple, undivided, secondary veins. But the studied material shows no separation between smaller pinnules within the larger structures, therefore these large, pinnae-like structures cannot be named pinnae here. Givulescu (1999) admitted that the large laminar lobes can be in fact fused pinnules into larger pinnae. However, the pinnae term is widely used in recent and in fossil material; and, in the recent, involving in living species, the term pinna is exclusively used (Mirza 2007; Salino et al. 2014). The recent Pronephrium parishii from Bangladesh has reduced, rounded teeth (Mirza 2007), like those of Pronephrium gymnopteridifrons and P. megacuspe from China (Zhang 2012), strongly different from those of $P$. articulatum, $P$. lakhimpurensis and $P$. nudatum developed in Bangladesh (Mirza 2007) and in China (Zhang 2012). 

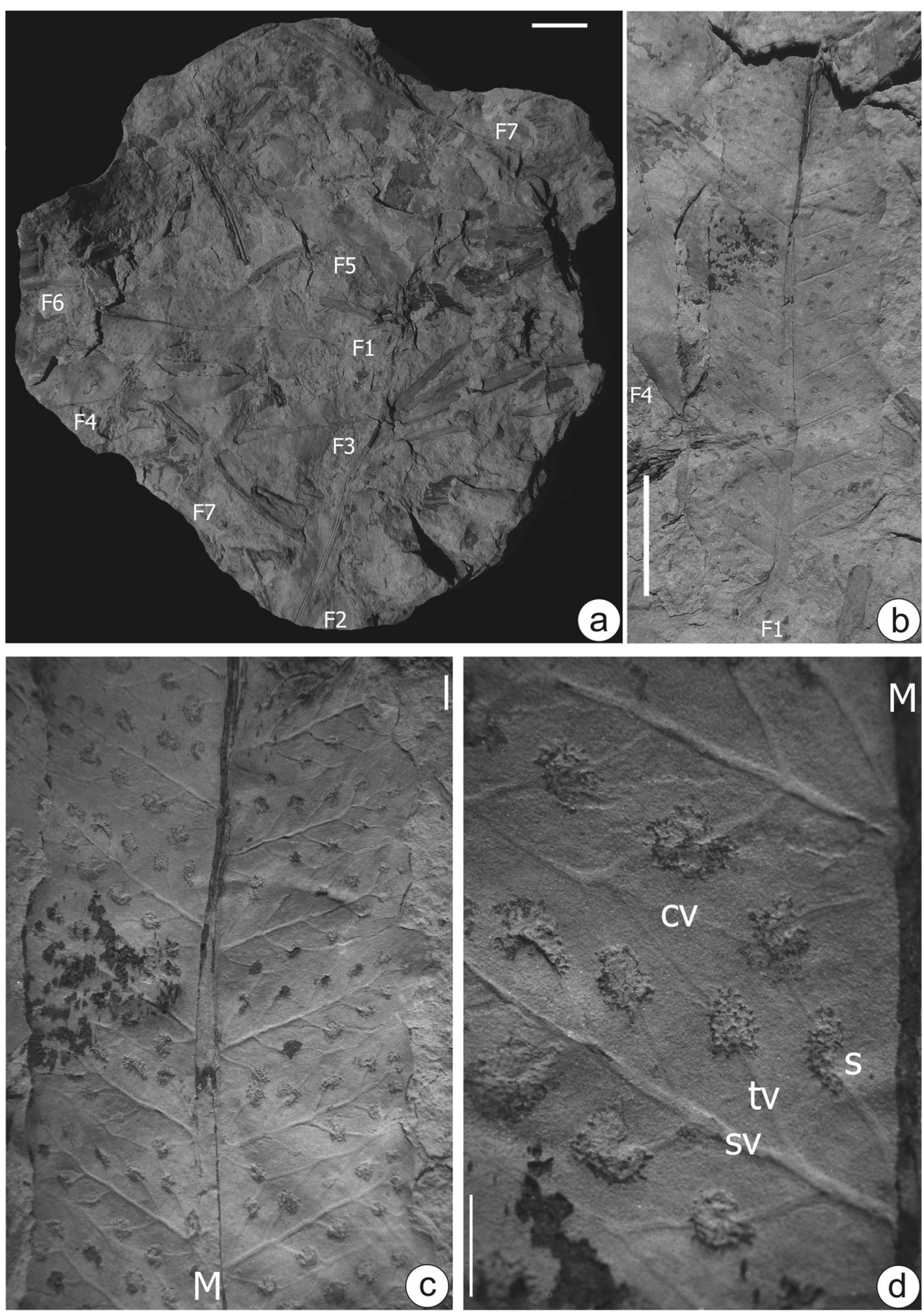

Fig. 8 Pronephrium stiriacum, fertile and sterile fragments, from Lighidia quarry, Miocene, Bozovici Basin. All from hand specimen LPBUV-0614, University of Bucharest, Department of Geology, Laboratory of Palaeontology. a General view of the hand specimen LPBUV-0614. F1: Fertile fragment, F2-F7: Sterile fragments. Scale bar: $10 \mathrm{~mm}$; b Fertile fragment (F1) and sterile fragment (F4). Scale bar: 1 mm; c Detail of fertile fragment (F1), showing the midrib (M), secondary, tertiary and connecting veins and sori. Scale bar: $1 \mathrm{~mm}$; d Detail of fertile fragment (F1), showing the midrib (M), secondary (sv), tertiary (tv) and connecting veins (cv) and sori (s). Scale bar: $1 \mathrm{~mm}$ 

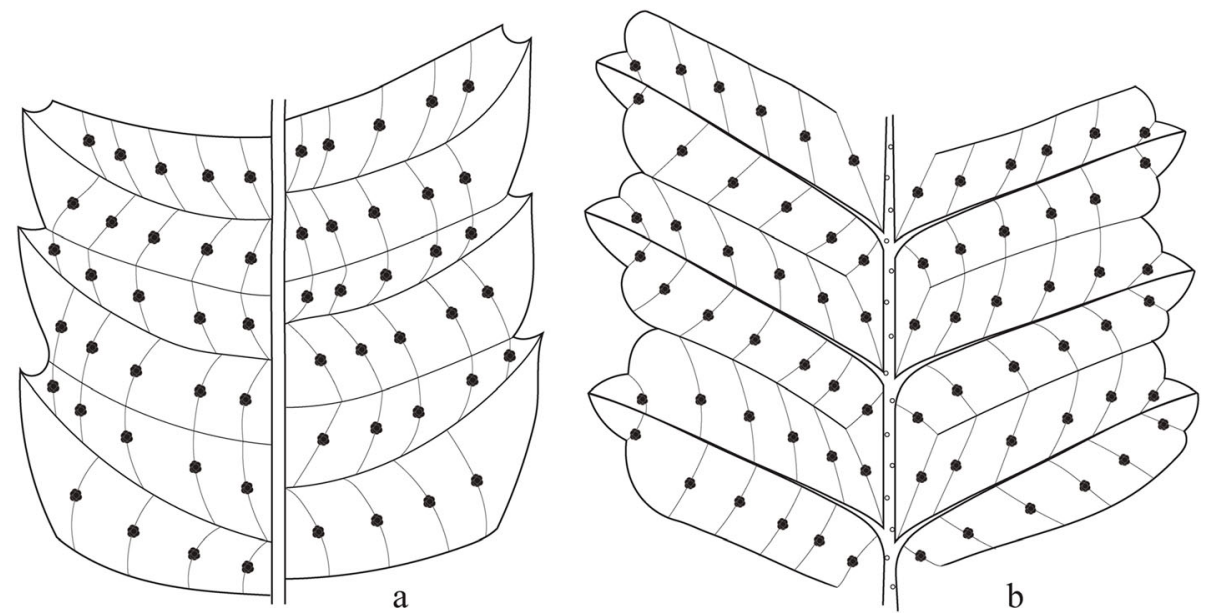

Fig. 9 Diagrams of the pinnules of Proneprhium stiriacum in Romania. a The Oligocene material from the Petroșani Basin; b The Miocene material from the Bozovici Basin

Unger (1847) defined Polypodites stiriacum under the following diagnosis: "Fronde pinnata, pinnis lienaribus elongatis serratis, nervis secundariis e nervo primario angulo subacuto egredientibus pinnatis, ramulis alternatibus obliquis parallelis trans medium soriferis". The type material was collected from Parschlug in Styria, Austria, and it is Miocene (Karpatian-early Badenian) in age (Kovar-Eder et al. 2004). The holotype showed in Unger (1847) in his Fig. 1 and plate 36 is a large fragment of an unipinnate frond with elongated-dentate pinnules, with marginal teeth of short-rounded apex, and with more acute apex which is rather symmetric (Figs. 2, 5) or slightly asymmetric (Fig. 4). Its connecting veins are strong and conspicuous, extremely alike with the Romanian Miocene material from Bozovici. Knobloch and Kvaček (1976) assigned their Bohemian Miocene material to Pronephrium stiriacum (Unger) Knobloch et Kvaček, making a new nomenclatorial combination. They also stressed the synonymy between Pronephrium Presl 1851 and Abacopteris Fee 1852, with Pronephrium having priority. Their material has elongated, large pinnules with symmetrical marginal teeth, similar to our Bozovici material. Givulescu (1996) described similar Pronephrium material under the name P. stiriacus, with falcate teeth along large pinnules and later (Givulescu 1999) under the name $P$. stiriacum. Pinnules were named pinnae by Givulescu $(1996,1999)$, and considered as a result from the fusion between regular pinnules. His material, which includes sori, was collected from Aninoasa and Vulcan (Petroșani Basin), and was studied in the collections of the Geological Institute of Romania in Bucharest (nos. P. 21224, P. 21225 from Aninoasa and P. 21228 from Vulcan). Givulescu (1986) only cited this species. Petrescu and Givulescu (1986) and Petrescu et al. (1997) cited and described Pronephrium stiriacum from the Petroșani Basin and from the Transylvanian Basin (Jac and Coruș). They considered the material as having dentate pinnules, not pinnae. Kvaček and Hurnik (2000) described Pronephrium stiriacum from the Miocene of the Czech Republic (Dobrcice locality), where it formed large leaf accumulations related to several swamp levels. The Czech material is also preserved in porcelanite, the leaves are fertile, with oppositely inserted pinnules, symmetrical marginal teeth and rather deep sinuses in between, very similar with our Bozovici Miocene material, although the connecting veins of the Czech material are not so prominent. Kvaček and Walther (1995, 1998) described Pronephrium stiriacum from the Oligocene tuffs of Suletice and Kundratice. Kvaček and Teodoridis (2007) only cited this species from the Czech Republic. Kovar-Eder et al. (2004) described the Miocene Pronephrium stiriacum from Austria, while Erdei and Wilde (2004) described a badly preserved fragment from Hungary, Oligocene in age. Kvaček et al. (2011) described Pronephrium stiriacum from the Miocene of France, with large pinnules and goniopterid venation. Hably (1985, 2013) considered the Miocene material as fused pinnules generating dentate pinnae, while Hably and Magyar (2013) only cited this species. Hably et al. (2015) described both fertile and sterile materials. Velitzelos et al. (2014) illustrated Pronephrium stiriacum with teeth apices very attenuated and rounded, almost entirely margined.

\section{Discussion}

Several morphological differences occur between the Petroșani (Aninoasa and Lupeni) Oligocene material and the Bozovici Miocene material. In Aninoasa, the pinnules are very elongated (Figs. 5, 6), while in Bozovici they tend to be shorter (Fig. 8). In Aninoasa, no hair bases occur along the midrib (Fig. 6b, c), while in Bozovici they are visible (Fig. 8b, c), a typical character of Thelypteridaceae. In Aninoasa, the marginal teeth are falcate and sharp (Fig. 6), 
but in Bozovici the marginal teeth are usually symmetrical and slightly rounded, with a median inflexion of the margin, between the apex and the sinus (Fig. 8a-c). In Aninoasa material, the interconnecting veins are very weak (Figs. 6, 7, 9a), while in Bozovici material they are much more prominent (Figs. 8, 9b). The sori are difficult to compare, considering the poor preservation of the Petroșani material. They are approximately of the same size, clustered irregularly with spherical sporangia. The distribution of the sori within the surface of the pinnules is approximately the same in both the Oligocene and the Miocene materials. Such differences point to ecological adaptations rather than to species differences, although recent, living species are separated on even finer morphological variations.

Pronephrium stiriacum has been recorded in the Oligocene and Miocene terrestrial formations of Europe (Fig. 1), but usually its descriptions and illustrations are brief, without considering its variations. The earliest occurrence of Pronephrium stiriacum is recorded in Czechia, in the Upper Eocene deposits of North Bohemia at Kučlín (Kvaček and Teodoridis 2011). Some Oligocene fragments of Pronephrium stiriacum were described from North Bohemia, in Suletice and in Kundratice (Kvaček and Walther 1998). In the Dobrčice area, Pronephrium stiriacum was described from the Lower Miocene porcelanite beds (Kvaček and Hurnik 2000). In northwestern Bohemia it was described from the Lom Formation of the Most Basin (Teodoridis and Kvaček 2006; Teodoridis 2007) as rare fragments, Miocene in age. In the westernmost part of Bohemia, Pronephrium stiriacum was cited from the Cypris Formation of both Cheb and Sokolov basins, Early Miocene in age, and also from the Nové Sedlo Formation, but Oligocene in age (Kvaček and Teodoridis 2007). From Doupovské hory Mountains, between the Sokolov and the Most basins, a few sites with the Oligocene floristic assemblages yield Pronephrium stiriacum remains. From the Bohemian part of the Zittau Basin, close to the state boundary of Germany, Pronephrium stiriacum was described from the Upper Coal Seam of the Hrádek Formation (Kvaček and Teodoridis 2007), Middle Miocene in age. In Germany, Pronephrium stiriacum was only described from the Oligocene diatomite deposits of Seifhennersdorf, Saxony Region (Walther and Kvaček 2007). In Hungary, Pronephrium stiriacum has a high frequency in both the Oligocene and the Miocene deposits. From Oligocene deposits abundant remains were described from the Mány Formation (Hably et al. 2015), outcropping in Környe. Discussing its ecology, Hably et al. (2015) considered this species as indicating wet environments. It also has been described from an Upper Oligocene sequence of Central Paratethys at Eger-Wind brickyard (Kvaček and Hably 1991) and from the Dorog Basin at Csolnok (Erdei and Wilde 2004). Pronephrium stiriacum was cited from the Miocene of Ipolytarnóc (Hably 1985), close to the northern rim of the Pannonian Basin, and from the Miocene sedimentary deposits of the Pannonian Basin at Balatonszentgyörgy, Felsőtárkány, Sé and Visonta (Hably 2013). From the Miocene of Austria, Pronephrium stiriacum was only described from the Parschlug Basin (Kovar-Eder et al. 2004) as a single, poorly preserved fragment. In Romania, Pronephrium stiriacum occurs in the Oligocene deposits of the Transylvanian Basin at Coruș (Givulescu 1968), Jac (Petrescu 1968, 1970), and Cornești (Petrescu et al. 1997); and in the Oligocene deposits of the Petroșani Basin (Givulescu 1986). Its occurrence in the Bozovici Basin is here reported for the first time for the Miocene deposits of Romania. In the Cenozoic floras of Greece, Pronephrium stiriacum was cited from the Oligocene beds at Lagina and Fylakton, Evros Region (Velitzelos et al. 2002); from the Lower Miocene sequences at Grevena and Mudros, Lemnos Region (Berger 1953; Süss and Velitzelos 1993); and from the Upper Miocene deposits in Strymon Basin (Velitzelos 1993) and of the Platana Formation (Kleinhölter 1994; Velitzelos et al. 2014). In southwestern France, Kvaček et al. (2011) described Pronephrium stiriacum from the Miocene of Arjuzanx.

The first attempt for reconstructing the Oligocene flora of the Petroșani Basin was undertaken by Givulescu (1996) based on the very first, general reconstructions of Teichmüller (1958) and Knobloch (1977). In this reconstruction, Givulescu (1996) placed Pronephrium stiriacum in the shrub peat bog zone. It was described as a flooding-prone zone and it was dominated by Myrica, Cyrilla, Osmunda, Blechnum, Calamus and numerous lauraceous taxa such as Daphnogene.

A vegetation reconstruction from Seifhennersdorf, Germany (Walther 1977; Walther and Kvaček 2007) was placing Pronephrium stiriacum in the monocot-fern swamp undergrowth, along with Osmunda lignitum and moncots such as Spirematospermum wetzleri, pointing out that the undergrowth vegetation breed as well along the water courses, under the canopy. The remains of frogs and salamanders in the same bed with Pronephrium stiriacum and its associated taxa, strengthen the idea of a humid palaeoenvironment.

In the flora of Környe, Hungary, Pronephrium stiriacum represented the dominant fern according to Hably et al. (2015). All the associated taxa with Pronephrium have affinities for water bodies: Glyptostrobus, Nyssa and Alnus. Also, the high frequency of the lauraceous taxa such as Daphnogene fits best a hygrophyte plant palaeocommunity.

The well-preserved fronds of Pronephrium stiriacum in both Petroșani and Bozovici basins suggest the short distance transportation of the material and underline its autochthonous character. Considering our taphonomical data and the former palaeoecological reports, we can also assess that Pronephrium stiriacum was thriving 
near to the water bodies, in a warm environment, during the Oligocene-Miocene timespan in the Petroșani and Bozovici basins.

Moreover, this palaeoecological context of Pronephrium stiriacum also emphasizes the coal generating character of this species. This species is frequently found in the roof shales of various coal seams, therefore it is a coal generator. Although it was not a swamp dweller, such as reeds were, it contributed to genesis of coal as it could quickly cover the mire areas in their closing phases, as an opportunistic species. Popa (1998, 2014) defined these species as secondary coal generators, in contrast with the primary coal generators which are represented by swamp dwellers. The secondary coal generators were not swamp dwellers, but they were opportunistic species which jumped in the closing mire, therefore contributing to the coal genesis and therefore were deposited also in the roof shales of the coal seams (Popa 1998, 2014). Such a coal genesis mechanism was described by Popa $(1998,2014)$ for European and Greenlandic Triassic and Jurassic coals, with primary coal generators such as sphenopsids and conifers, and secondary coal generators represented by a ternary association between a fern, a bennettitalean and a ginkgoalean representative, also called by Popa (2014) as a ternary rule. This ternary rule was later demonstrated statistically by Barbacka et al. (2016). Now it can be demonstrated that during the Cenozoic times, Ponephrium stiriacum played the same role as a secondary coal generator, the same way a fern representative played during the Jurassic within its ternary association.

\section{Conclusions}

Pronephrium stiriacum (Filicales, Thelypteridaceae) material was collected from the Oligocene sediments of the Petroșani Basin (Aninoasa, an underground coal mine) and from the Miocene sediments of the Bozovici Basin (Lighidia open cast mine), showing a series of morphological variations during the Oligocene-Miocene time interval. Such variations include venation, pinnule margins and sorus size, and they indicate local ecological variations in the habitat of this fern. Although intensively occurring in the fossil material with this stratigraphic range, these variations are not strong enough for segregating Pronephrium stiriacum into separate Oligocene and Miocene species. From a palaeoecological point of view, this species was not a swamp dweller, although it generated coal as a successful secondary coal generator in the Cenozoic phytocoenoses.

\section{Acknowledgements}

The authors wish to thank Prof. Grigore Buia, Dr. Lorinț Csaba and Dr. Ciprian Danciu from the University of Petroșani, for their help during our field activities in the Petroșani Basin. We thank Mr. Alexandru Călin for his kind help in the field, in the Bozovici Basin. Mr. Cristian Țopescu and Mrs. Elisabeta Topescu from Petroșani are warmly thanked for helping in the field. We thank Prof. Lilla Hably from the Eötvös Loránd University, Hungary, and
Prof. Cheng-Sen Li from the Institute of Botany, Chinese Academy of Sciences, China, for thoroughly reviewing the manuscript. We thank Prof. Johanna Eder from the Staatliches Museum für Naturkunde Stuttgart, Germany, Prof. Lilla Hably and Prof. Zlatko Kvaček from the Charles University, Czech Republic, and Dr. Irene Zorn from the Geologische Bundesanstaldt, Austria, for their help in providing palaeobotanical literature. The staff of the Mining Museum in Petroșani is also thanked for their kind help. Dr. Valentin Paraschiv is thanked for granting access to the collections of the National Geological Museum of the Geological Institute of Romania, Bucharest.

\section{Authors' contributions}

Both authors read and approved the final manuscript.

\section{Competing interests}

The authors declare they have no competing interests.

\section{Publisher's Note}

Springer Nature remains neutral with regard to jurisdictional claims in published maps and institutional affiliations.

\section{Author details}

${ }^{1}$ Faculty of Geology and Geophysics, Doctoral School of Geology, University of Bucharest, 1, N. Bălcescu Ave, 010041 Bucharest, Romania. ${ }^{2}$ Faculty of Geology and Geophysics, Department of Geology, Laboratory of

Palaeontology, University of Bucharest, 1, N. Bălcescu Ave, 010041 Bucharest, Romania.

Received: 19 March 2018 Accepted: 3 May 2018

Published online: 20 September 2018

\section{References}

Barbacka, M., M.E. Popa, J. Mitka, E. Bodor, Z. Püspöki, and R.W. Mclntosh. 2016. A quantitative approach for identifying plant ecogroups in the Romanian early Jurassic terrestrial vegetation. In Palaeogeography, Palaeoclimatology, Palaeoecology 446: 44-54.

Berger, W. 1953. Jungtertiäre Pflanzenreste aus dem Gebiete der Ägäis (Lemnos, Thessaloniki). Annales Géologiques des Pays Helléniques 5: 34-65.

Codrea, V. 2001. Badenian insectivores from Bozovici Basin (southern Carpathians, Caraș-Severin District). In Acta Palaeontologica Romaniae 3: 67-75.

Erdei, B., and V. Wilde. 2004. An Oligocene leaf assemblage from Csolnok, Dorog Basin, N Hungary. In Revue de Paleobiologie 23: 117-38.

Givulescu, R. 1968. Ein neuer Beitrag zur Kenntnis der fossilen Flora von Coruș bei Cluj (Rumänien). Geologie 17 (5): 572-605.

Givulescu, R. 1986. Etude sur la végétation fossile de la Vallée du Jiu (Departement de Hunedoara). Dări de Seamă ale Sedințelor Institutului de Geologie și Geofizică 70-71 (3): 171-186.

Givulescu, R. 1996. Flora oligocenă superioară din Bazinul Petroşani. Cluj-Napoca: Casa Cărții de Ştiință.

Givulescu, R. 1999. Flora mică ilustrată a Terțiarului din România. Cluj-Napoca: Casa cărții de ştiință.

Hably, L. 1985. Early Miocene plant fossils from Ipolytarnóc, northern Hungary. Geologica Hungarica, Series Palaeontologica 45: 73-256.

Hably, L. 2013. The Late Miocene flora of Hungary. Budapest: Geological and geophysical institute of Hungary.

Hably, L., B. Erdei, and I. Selmeczi. 2015. A late Oligocene (Egerian) flora from Környe, near Tatabánya, N Hungary. Neues Jahrbuch für Geologie und Paläontologie 276 (3): 285-302.

Hably, L., and I. Magyar. 2013. Palaeobotanical localities: Geology, fossils, flora, vegetation and environment. Geologica Hungarica Series Palaeontologica F59: 15-35.

Heer, O. 1872. Ueber die Braunkohlen-Flora des Zsily-Thales in Siebenbürgen. Pest: Druck von Knor \& Wein.

Holttum, R.E. 1971. Studies in the family Thelypteridaceae. III. A new system of genera in the Old World. Blumea 19: 17-52.

\|liescu, O. 1967. Geologia Bazinului Bozovici. In Dări de Seamă ale Institutului de Geologie şi Geofizică, 53.

Kleinhölter, K. 1994. Zur stratigraphischen Einstufung der Platana-Formation im Pyrgos- und Zachara-Becken (West-Peloponnes, Griechenland). Münstersche Forschungen zur Geologie und Palaeontologie. 76: 263-270.

Knobloch, E. 1977. Die Entstehung Jungtertiarer Braunkohlen aus Palaobotanischer. Cour. Forsch. Inst. Senckenberg 24: 68-71. 
Knobloch, E., and Z. Kvaček. 1976. Miozane Blätterfloren vom Westrand der Böhmischen Masse. Prague: Vydal Ústřední Ústav Geologický.

Kovar-Eder, J., Z. Kvaček, and M. Ströbitzer-Hermann. 2004. The Miocene Flora of Parschlug (Styria, Austria) - revision and synthesis. In Annalen des Naturhistorischen Museums in Wien 105A: 45-159.

Kvaček, Z., and L. Hably. 1991. Notes on the Egerian stratotype flora at Eger (wind brickyard), Hungary, Upper Oligocene, Annales Historico-Naturales Musei Nationalis Hungarici 83.

Kvaček, Z., and S. Hurnik. 2000. Revision of Early Miocene plants preserved in baked rocks in the north bohemian tertiary. In Acta Musei Nationalis Pragae, Historia Naturalis 56: 1-48.

Kvaček, Z., and V. Teodoridis. 2007. Tertiary macrofloras of the bohemian massif: A review with correlations within boreal and Central Europe. Bulletin of Geosciences 82 (4): 83-408.

Kvaček, Z., and V. Teodoridis. 2011. The late Eocene flora of Kučlín near Bílina in north bohemia revisited. Acta Musei Nationalis Pragae, Series B - Historia Naturalis 67 (3-4): 83-144.

Kvaček, Z., V. Teodoridis, and P. Roiron. 2011. A forgotten Miocene mastixioid flora of Arjuzanx (Landes, SW France). Palaeontographica Abteilung BPalaophytologie 285: 3-111.

Kvaček, Z., and H. Walther. 1995. The Oligocene volcanic flora of Suletice-Berand near Ústí Nad Labem, north bohemia - a review. Acta Musei Nationalis Pragae, Series B - Historia Naturalis 50 (1-4): 25-54.

Kvaček, Z., and H. Walther. 1998. The Oligocene volcanic flora of Kundratice near Litoměřice, České Středohoři volcanic complex (Czech Republic) - a review. Acta Musei Nationalis Pragae, Series B - Historia Naturalis 54 (1-2): 1-42.

Mateescu, I. 1956. Studiul petrografic al cărbunilor din Bazinul Văii Jiului cu privire specială asupra cărbunilor din regiunea Uricani-Câmpul lui Neag. Annuaire du Comité Géologique 29: 125-195.

Mateescu, I. 1960. Etude petrographique des charbons du Bassin de la Valee du Jiu, avec apercu special sur les charbons de la region Uricani-Cîmpul lui Neag (Basin de Petroşani). Annuaire du Comité Geologique 29-30: 39-55.

Mirza, M.M. 2007. The genus Pronephrium C. Presl (Thelypteridaceae) from Bangladesh. Bangladesh Journal of Plant Taxonomy 14: 37-45.

Pax, F. 1908. Grundzüge der Pflanyenverbreitung in der Karpathen. Leipzig: Verlag von Wilhelm Engelmann.

Petrescu, I. 1968. Etude preliminaire de la flore Oligocene de la Valea Cetății (Roumanie). Bulletin Mensuel de la Société linnéenne de Lyon 37: 294-302.

Petrescu, I. 1970. Sur la flore oligocéne du Jac (Bassin de Agrișului-Roumanie). Bulletin Mensuel de la Société linnéenne de Lyon 39: 293-296.

Petrescu, I., and R. Givulescu. 1986. Flore et vegetation de la Vallee du Jiu (Bassin de Petrosani), Roumanie. Revue de Paléobiologie 5 (1): 109-116.

Petrescu, I., R. Givulescu, and O. Barbu. 1997. Macro- şi Microflora Oligocenă de la Cornesti-Arghireș, România. Cluj-Napoca: Editura Carpatica.

Petrescu, I., E. Nicorici, C. Bițoianu, N. Țicleanu, C. Todros, M. Ionescu, G. Mărgărit, M. Nicorici, A. Duşa, I. Pătrutoiu, A. Munteanu, and A. Buda. 1987. Geologia zăcămintelor de cărbuni. 2. Zăcăminte din România. Bucharest: Editura Tehnică.

Pop, E.l. 1959. Studiul geologic al Bazinului Bozovici. Buletinul Institutului de Mine Petroșani 6: 79-95.

Popa, M.E. 1998. The Liassic continental flora of Romania: Systematics, stratigraphy and paleoecology. Acta Botanica Horti Bucurestensis 1997-1998: 177-184.

Popa, M.E. 2011. Field and laboratory techniques in plant compressions: An integrated approach. Acta Palaeontologica Romaniae 7: 279-283.

Popa, M.E. 2014. Early Jurassic bennettitalean reproductive structures of Romania Palaeobiodiversity and Palaeoenvironments 94: 327-362.

Preda, I., and C. Nedelcu. 1987. "Les processes de diagenese de charbons de Bozovici." Analele Universității Din București, Seria Geologie 34

Preda, I., I. Turculeț, A. Bădăluță, T. Barus, and A. Androhovici. 1994. Geologia zăcămintelor de cărbuni. In Partea a II-a. Răspândirea zăcămintelor de cărbuni. Bucureşti: Editura Universității din Bucureşti.

Răileanu, G. 1955. Cercetări geologice în regiunea Cluj - Apahida - Sic. In Dări de seamă ale Institutului Geologic, XXXIX, 128-145.

Răileanu, G., N. Grigoraș, N. Oncescu, and T. Plișcă. 1963. Geologia zăcămintelor de cărbuni, cu privire specială asupra teritoriului RPR. Bucureşti: Editura Tehnică.

Salino, A., M.G.M. De Souza, and A.J. Arruda. 2014. Thelypteris indusiata (Thelypteridaceae), a new fern species from Amazonian Brazil. Phytotaxa 156: 279-284.

Staub, M. 1887. Die aquitanische Flora des Zsilthales im Comitate Hunyad. Mittheilungen aus dem Jahrbuche der Kgl. ungarischen Geologischen Anstalt 7 (6): 3-197.
Stur, D. 1863. Bericht über die geoloische Übersichtsaufnahme des südliches Siebenbürgen im Sommer 1860. Jb. k. k. Geol. R.-A. 13: 33-120.

Süss, $H_{\text {., }}$ and E. Velitzelos. 1993. Eine neue Protopinaceae der Formgattung Pinoxylon Knowlton emend. Read, P. parenchymatosum sp. nov., aus tertiären Schichten der Insel Lemnos, Griechenland. Feddes Repertorium 104: 335-341.

Teichmüller, R. 1958. Rekonstruktionen verschiedener Moortypen des Hauptflözes der niederrheinischen Braunkohle. Fortschritte in der Geologie von Rheinland und Westfalen 2: 721-750.

Teodoridis, V. 2007. Revision of Potamogeton fossils from the most basin and their palaeoecological significance (Early Miocene, Czech Republic). Bulletin of Geosciences: 409-418. https://doi.org/10.3140/bull.geosci.2007.04.409.

Teodoridis, V., and Z. Kvaček. 2006. Palaeobotanical research of the Early Miocene deposits overlying the main coal seam (Libkovice and Lom members) in the most basin (Czech Republic). Bulletin of Geosciences 81: 93-113.

Unger, F. 1847. Chloris protogaea: Beitrage zur Flora der Vorwelt. Leipzig: W. Engelmann.

Velitzelos, D., J.M. Bouchal, and T. Denk. 2014. Review of the Cenozoic floras and vegetation of Greece. Review of Palaeobotany and Palynology 204: 56-117.

Velitzelos, E. 1993. Neue paläofloristische Daten zu känophytischen Floren Griechenlands. Documenta Naturae 87: 1-17.

Velitzelos, E., Z. Kvaček, and D. Velitzelos. 2002. "New Oligocene leaf floras from the volcanic complex of the Evros Mountains." 6th European Paleobotanypalynology conference Athens, Greece, 185-186.

Walther, H. 1977. Versuch der Rekonstruktion einer ter- tiären Landflora am Beispiel von Seifhennersdorf. Abhandlungen und Berichte des Naturkundemuseums Görlitz 51 (2): 23-25.

Walther, H., and Z. Kvaček. 2007. Early Oligocene Flora of Seifhennersdorf (Saxony). Acta Musei Nationalis Pragae 63 (2-4): 85-174.

Zhang, X.-C. 2012. Lycophytes and Ferns of China. Beijing: Peking University Press.

\section{Submit your manuscript to a SpringerOpen ${ }^{\circ}$ journal and benefit from:}

- Convenient online submission

- Rigorous peer review

- Open access: articles freely available online

- High visibility within the field

- Retaining the copyright to your article

Submit your next manuscript at $>$ springeropen.com 